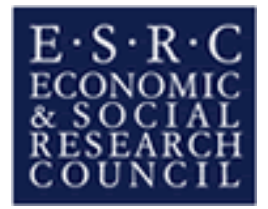

\title{
Efficiency and Price Effects of Horizontal Bank Mergers
}

by

\author{
John Ashton
}

Norwich Business School and the ESRC Centre for Competition

Policy, University of East Anglia

$\&$

\section{Khac Pham}

ESRC Centre for Competition Policy, University of East Anglia

\section{CCP Working Paper 07-9}

Abstract: This study provides an empirical assessment of the efficiency and interest rate changes occurring during 61 UK retail bank mergers. Key findings of the work include the general efficiency enhancing influence of UK bank mergers and the limited effect of merger on retail interest rates. Furthermore, different banking products appear to be influenced differently by mergers. It is proposed that future assessments of bank competition and mergers require an accommodation of different types of bank customer.

June 2007

JEL Classification Codes: G14, G21

Keywords: Retail banking, mergers, efficiency and price effects

\section{Acknowledgements:}

We would like to thank Moneyfacts PLC for the use of their extensive data sets of product information. Further we would like to thank Bruce Lyons and participants of seminars at Essex University and University of East Anglia for their helpful comments in the development of this work. All errors remain the responsibility of the authors. The support of the Economic and Social Research Council is also gratefully acknowledged.

\section{Contact details:}

John Ashton, Centre for Competition Policy, University of East Anglia,

Norwich, NR4 7TJ, UK

j.ashton@uea.ac.uk

Khac Pham, Centre for Competition Policy, University of East Anglia, Norwich, NR4 7TJ, UK

k.pham@uea.ac.uk 


\section{Introduction}

Comprehending the degree to which efficiency improvements from mergers are passed onto customers is a central concern when determining whether a merger may be legally undertaken. Further, the relationship between the efficiency and price changes which emerge from mergers is subject to much theoretical consideration (e.g. Davis and Wilson 2000, Farrell and Shapiro 1990, Froeb et al 2005, Spector 2003, Williamson 1968). Despite this interest, relatively little empirical assessment ${ }^{1}$ has yet to emerge directly measuring these combined dynamic price and efficiency effects of mergers. Responding to this paucity of analysis, this study provides an empirical assessment of the degree to which interest rates - the effective prices of many financial services - are influenced by horizontal retail bank mergers.

Three key findings of the study emerge. First, UK retail bank mergers between 1988 and 2004 have led to significantly enhanced cost efficiency for the merging banks. Second, the overall level of retail interest rates for most banking services is not significantly influenced by mergers. Three, contrasting banking products and products with distinct levels of financial involvement are affected differently by mergers.

This empirical assessment develops from an academic literature which has investigated the effect of mergers on retail interest rates and efficiency separately. Many studies have investigated the influence mergers have had on the efficiency of merged banks (see Amel et al 2004, Berger et al 1999 and Campa and Hernado, forthcoming). While this extensive international literature indicates that the efficiency

\footnotetext{
${ }^{1}$ For example Pesendofer (2003) provides an assessment of the US paper industry. Further NEIO studies have been undertaken by Azzam (1997), Azzam and Rosenbaum (2001), and Lopez et al (2002) as to the market power and efficiency effects of concentration in a range of markets including Portland cement, beef packing and food processing industries respectively.
} 
gains from bank mergers are limited, this evidence is less than conclusive. Past academic work as to performance changes arising from UK building society mergers (Barnes 1985 and Haynes and Thompson 1999) indicates both negative and positive performance effects of mergers.

Relatively few studies have considered the effects of retail bank mergers on the interest rates received by, or charged to, retail banking consumers. ${ }^{2}$ These assessments of consumer deposit (Focarelli and Panetta 2003, Prager and Hannan 1998) or unsecured loan (Kahn et al 2005) data have examined how merging banks and their rival banks within local markets change interest rates. This literature indicates that mergers occurring in more concentrated banking markets lead to adverse short-term deposit interest rate change (Prager and Hannan 1998). Longer-term post-merger deposit interest rate change can also be positive due to hypothesised medium-term efficiency changes (Focarelli and Panetta 2003). Additionally, distinct retail banking products are often affected differently by merger actions (Kahn et al 2005), with some banking products not being influenced by merger at all.

Despite the importance of all these contributions, a persistent policy concern is the degree to which efficiency gains from mergers are passed on to bank customers. This study addresses this issue through an examination of how both retail interest rates and efficiency changed after 61 UK retail bank horizontal mergers between 1988 and 2004. This examination is undertaken in six sections. After this introduction, a brief review of the wider academic literature is included. The research setting and data used in the study are discussed in section three. Section four provides the empirical testing

\footnotetext{
${ }^{2}$ A substantial literature has also developed assessing the effects of bank mergers for commercial rather than retail customers. Key recent contributions to this literature include Carrow et al 2006, Focarelli et al 2002, Karceski et al 2005 and Sapanieza 2002.
} 
framework and in section five the results of the analysis are presented. Lastly, a summary of the study is provided, conclusions are drawn and recommendations for policy makers are presented in section six.

\section{Literature Review}

This empirical investigation of efficiency and interest rate changes by merging banks contributes to the wider banking literature by addressing regulatory and theoretical concerns. These concerns are addressed in turn.

Initially, mergers between banks in many nations are subject to antitrust or competition law. ${ }^{3}$ Within the UK legal framework mergers between banks can be blocked when they are viewed to limit competition. ${ }^{4}$ Central to improving the competitiveness of a sector is both the achievement of efficiency or synergies from the mergers and the degree to which these efficiency savings will be passed on to customers. For example, a recent large UK bank merger between Lloyds TSB and Abbey National was expected to create substantial efficiency gains. This merger was blocked as the competition authority stated, amongst other reasons, that these efficiency gains would not be passed on to customers (Competition Commission 2001). This decision, emphasising the pass through of efficiency gains to customers over the realisation of efficiency gains alone, is consistent with the social equity and/or consumer welfare concerns which underpin competition law within Europe and the USA (Stuyck 2005). To summarise, an empirical understanding of how efficiency

\footnotetext{
${ }^{3}$ Over 100 nations have now developed their own antitrust or competition laws, rules and regulations following the US model of competition law (Djelic 2002).

${ }^{4}$ Before the UK Enterprise Act (2002) the criteria was the public interest. A discussion of whether efficiency gains should be incorporated within a merger control regime more generally is given by Röller et al (2000).
} 
gains are passed on to customers after bank mergers has a substantial regulatory importance for both those wishing to merge and the regulators of such change.

Secondly, assessment of the relationship between efficiency and price changes after mergers has been the focus of much theoretical examination. Farrell and Shapiro (1990) assert that prices will only fall after a merger if substantially lower marginal costs exist relative to the marginal costs of the two merging firms before the merger. Conversely if a merger generates no efficiencies (synergies) then prices faced by customers will rise. Within this framework a profitable merger will only be socially beneficial in a limited number of cases where efficiency has risen substantially and this benefit has been passed on to consumers. Thus the relationship between efficiency and price change should be positive when interest rates represent a benefit to the customer, as is the case for deposits, and negative when they represent a cost to the customers, as is the case for lending.

This contribution has led to a range of theoretical developments. In assessing the link between pricing, efficiency and competition, Davis and Wilson (2000) indicate that the initial efficiency levels of the merging firms have a substantial influence on the level of competition engendered by the merged firm. As a result the degree of pass through of efficiency after mergers may be influenced by the initial efficiency endowment of the merging firms. Further contributions from Bulow and Pfleiderer (1985) and Ten Kate and Niels (2005) emphasise the limited influence that price elasticity of demand or market share imposes on the degree of efficiency gains passed on to the consumer in different competition forms. This last position indicates the 
market structure often has a negligible influence on the pass through of efficiency gains. From this literature, three hypotheses can be defined and subsequently tested:

- Bank mergers will generally result in adverse conditions for consumers if a merger has no efficiency gains.

- Relative price improvements for customers will occur only when substantial efficiency gains are recorded after a merger event.

- The duration over which efficiency and interest rates change after mergers have occurred can be substantial and different banking products may be affected by bank mergers in different ways.

The approaches through which these hypotheses are empirically assessed are examined in the next section.

\section{Research Setting and Data}

\subsection{Research Setting}

The assessment of the research hypotheses is undertaken in the setting of the UK retail banking market. This relatively concentrated market, with a limited number of large banks and a large fringe of smaller banks, has appreciated a considerable amount of merger activity during the last decade. To illustrate the relationship between interest rates and efficiency in bank mergers, UK retail banks and building societies are examined. UK building societies are mutually-owned financial institutions, similar to US savings and loans institutions; and retail banks are shareholder-owned large banks. All these institutions generally offer a wide array of different retail banking services. 
In generating the sample of UK merging banks between 1988 and 2004 we employ a number of screens. Initially only banks involved in the UK domestic retail banking market are included. Secondly, only horizontal mergers are considered. As only those banks are selected for which a panel of accounting and price data could be obtained, two bank mergers are excluded as the data was unavailable. In total this selection leaves 105 banks and building societies which are involved with 61 banking mergers. ${ }^{5}$ This selection is viewed to constitute close to the wider population of domestic bank mergers undertaken in the UK over the period 1988 to 2004.

This selection includes mergers which occurred most frequently between relatively small institutions, particularly mutually-owned building societies. Only a limited number of very large domestic mergers, such as that between Natwest and the Bank of Scotland, were recorded. Within the selection process acquiring and target banks are identified. This classification is made to reference the definitions of acquiring and target banks used by the British Bankers Association and the British Building Societies Association. ${ }^{6}$ In addition, a number of proposed bank mergers have been investigated and in some cases blocked by the UK competition authorities. While this potential bias is acknowledged, most of the mergers considered in this assessment have not been subject to this process due their relatively small scale.

\subsection{Data used in the study}

The data for this study comes from three sources. Annual reports and accounts of 105 individual banks over the period 1988 to 2004 are used to provide most of the data for the examination of efficiency. Additional data on staff numbers is provided by the

\footnotetext{
${ }^{5}$ The 61 mergers assessed are reported in Appendix 1.

${ }^{6}$ In cases where such definition is not possible reference to contemporary press commentary and scale of partners involved in the mergers are used to define targets and acquirers.
} 
British Bankers Association Annual Abstract of Statistics. To assess the interest rate changes substantial data sets of interest rates for deposits, unsecured lending and mortgages are employed, which were provided by Moneyfacts PLC, a widely used data provider for the UK financial services industry. This data source is also employed in regulatory and academic examinations of the UK financial services industry (e.g. Competition Commission 2001, Cruickshank 2000, Heffernan 2005, 2006) and provides a comprehensive survey of all market participants in the UK deposit, mortgage and unsecured personal lending markets. The data sets are contiguous yet unbalanced due to the entry and exit of both financial products and banks from individual markets (see Costanzo and Ashton 2006).

The deposit interest rate data are provided for instant access accounts and notice accounts. These two deposit products are issued by 104 banks, for 3 different deposit values ranging from small $(£ 500)$, medium $(£ 5,000)$ and large $(£ 50,000)$ deposits. These values are chosen as they are distinct and do not overlap due to the effect of inflation. The mortgage data are the reference interest rates from which the interest charged on different mortgage contracts for existing mortgage customers is assessed. These data are provided for 99 banks in total. The unsecured personal lending data are provided at three levels of lending for relatively small $(£ 1,000)$, medium $(£ 5,000)$ and large quantities $(£ 10,000)$. These data are recorded for 52 banks in total. All the interest rate data are provided at monthly intervals over an 18 year period from 1988 to 2004 , providing 162,972 observations for deposits, 14,455 observations for mortgages and 4,249 observations for unsecured lending. The product data are pooled for different product characteristics and forms of distribution. 


\section{The Testing Framework}

Two approaches are employed to test for the effects of bank merger on interest rates and cost efficiency. First, the cost efficiency of both merging and non-merging banks is calculated. Second, a regression model is estimated to ascertain the link between interest rates and merger events for all the banks in our sample. These procedures are discussed in turn.

\subsection{Efficiency Estimation}

The level of bank-specific annual cost efficiency is estimated using a stochastic frontier model, where productive technology is represented by a flexible Fourier functional form. The model is estimated using an unbalanced data panel including banks which have and have not merged over the period 1988 to 2004. This approach is deemed to be superior to other methods of estimating efficiency, such as data envelopment analysis ${ }^{7}$ (Charnes et al 1978, Banker et al 1984) due to the stochastic form of the frontier estimated. Cost efficiency is estimated in this study, rather than alternative efficiency measures such as profit efficiency (see Berger and Humphrey 1997), as the sample of banks have a variety of objective functions. For example while retail banks may be assumed to be profit-maximising institutions, mutuallyowned building societies may be maximising a range of alternative objectives (see Drake and Llewellyn 2001 and Nichols 1967).

\footnotetext{
${ }^{7}$ Efficiency was also estimated using this DEA approach. Whilst the findings were broadly similar to the estimates recorded here, this approach was viewed to be less able to accommodate a diverse range of productive technologies and subsequently is not reported in this study.
} 
Table 1: Descriptive Statistics (adjusted for inflation)

\begin{tabular}{|c|c|c|c|c|}
\hline Definition & Mean & Std. Dev. & Min. & Max. \\
\hline $\begin{array}{c}\text { Total cost - operating and } \\
\text { financial costs (£m) }\end{array}$ & 1224.85 & 3389.22 & 0.61 & 24095 \\
\hline Total Fixed Assets (£m) & 375.80 & 1930.84 & 0.02 & 33870 \\
\hline Total Staff Employed & 4918.491 & 14893.61 & 4 & 98400 \\
\hline Total Borrowings (£m) & 15849.73 & 47148.56 & 0.00 & 464271 \\
\hline $\begin{array}{c}\text { Management Expenses } \\
(£ m)\end{array}$ & 404.70 & 1349.54 & 0.07 & 14653 \\
\hline Staff Costs (£m) & 156.03 & 555.07 & 0.31 & 5231 \\
\hline All Loans (£m) & 12529.94 & 35307.12 & 4.18 & 345469 \\
\hline Liquid Assets (£m) & 4328.84 & 17314.15 & 1.35 & 212742 \\
\hline Total Assets (£m) & 19412.90 & 59565.80 & 0.00 & 583467 \\
\hline Depreciation (£m) & 36.444 & 127.649 & 0.007 & 1686.170 \\
\hline $\begin{array}{c}\text { Profits or Reserves } \\
\text { Retained (£m) }\end{array}$ & 127.965 & 452.192 & -1208.511 & 4762.000 \\
\hline $\begin{array}{c}\text { Provisions for bad and } \\
\text { doubtful loans (£m) }\end{array}$ & 65.372 & 258.986 & -48.556 & 3331.216 \\
\hline Interest Received (£m) & 1128.56 & 2963.52 & 0.18 & 22449 \\
\hline Interest Paid (£m) & 820.15 & 2180.75 & 0.44 & 17318 \\
\hline \multicolumn{2}{|c|}{ Obs. 1394 } & & \\
\hline
\end{tabular}

Within the efficiency model total costs include both the bank's operating and financial costs following an intermediation approach (Sealey and Lindley 1977). Outputs are quantified by their value. The price of labour $\left(P_{1}\right)$ is proxied by the total wage bill divided by the number of full time equivalent employees. The price of capital $\left(P_{2}\right)$ is represented by the total capital expenses including depreciation costs, divided by total fixed assets. The price of deposits $\left(P_{3}\right)$ is represented by total interest payable divided by the quantity of deposits. These definitions of inputs and outputs are broadly consistent with other European and UK studies of bank efficiency (e.g. Altunbas et al 1997, 2001, Ashton 2001a, Casu and Girardone 2006). Descriptive statistics adjusted for 2004 prices $^{8}$ of these data are provided in Table 1.

\footnotetext{
${ }^{8}$ Adjusted using the Retail Price Index including the costs of mortgage payments. This data series was provided by the Bank of England.
} 
The procedure for estimating the model follows the general frontier cost function proposed by Aigner et al. (1977) and Meeusen and Van den Broeck (1977). This stochastic frontier, estimated using panel data can be represented as:

$$
C_{i t}=C\left(P_{i j t}, Y_{i g t}\right) \cdot e^{V_{i t}+U_{i t}} \quad j=1,2, \ldots N ; g=1,2, \ldots N
$$

and represented as (2) in logarithmic form:

$$
L n C_{i t}=f\left(P_{i j t}, Y_{i g t}\right)+\ln V_{i t}+\ln U_{i t} \quad j=1,2, \ldots N ; g=1,2, \ldots N
$$

where: $C_{i t}$ represents a scalar cost of $i^{\text {th }}$ bank in the $t^{\text {th }}$ period; and $f$ denotes a functional form. $P_{i j t}$ is a vector of the $j^{\text {th }}$ input price used by $i^{\text {th }}$ bank in the $t^{\text {th }}$ period; $Y_{i g t}$ is a vector of $i^{\text {th }}$ bank's output in the $t^{\text {th }}$ period. The error term $V_{i t}$ assumed to be independently and identically distributed represents the effect of random shocks (noise) and is independent of $U_{i t}$, the inefficiency term which represents technical inefficiencies. Following the Battese-Coelli (1992) parameterisation of time effects, the technical inefficiency term is assumed to have a truncated-normal distribution.

After estimating a particular cost function using a maximum likelihood estimator, the individual cost efficiency for bank $i^{\text {th }}$ in the $t^{\text {th }}$ period relative to cost frontier is estimated according to the ratio between the minimum cost $\left(C_{\min }\right)$ necessary to produce that bank's output and the actual cost $\left(C_{i}\right)$, such as:

$$
\text { Cost Efficiency }{ }_{i t}=\frac{C_{\min }}{C_{i t}}=\frac{\exp [f(y, w, z)]}{\exp [f(y, w, z)]} \frac{\exp \left(\ln u_{\min }\right)}{\exp \left(\ln u_{i t}\right)}=\frac{u_{\min }}{u_{i t}}
$$


The productive technology in this model is represented by a flexible Fourier functional form (see Gallant 1981, 1982). The flexible Fourier functional form is a second order polynomial with a combination of sine and cosine functions in the explanatory variables. This form is Sobelev flexible form, estimates elasticities consistently and reduces specification bias when representing diverse productive technologies (Gallant 1981, 1982, Ivaldi et al 1996).

The method for defining variables follows the approach established by Mitchell and Onvural (1996). The trigonometric transformations of the variables are functions that re-scale the periodic sine and cosine values so that they fall within a sample-specific domain of $(0,2 \pi)$. Chalfant and Gallant (1985) and Mitchell and Onvural (1996) indicate that the semi-non-parametric sample-specific scaling procedure may be simplified through the imposition of a number of a priori assumptions allowing the flexible Fourier series expansion to be used as an effective expansion technique (Rossi 1985). The non-parametric sample-specific scaling procedure employed is denoted:

$p_{r}^{\min }, p_{r}{ }^{\max }=$ sample minimum/maximum for the $r^{\text {th }}$ input price

$y_{j}^{\min }, y_{j}{ }^{\max }=$ sample minimum/maximum for the $j^{\text {th }}$ output quantity

$W p_{r}=0.00001-\operatorname{Lnp}_{r}{ }^{\min }, \quad W y_{i}=0.00001-\operatorname{Lny}_{j} \min ^{\min }$

$M=L n p_{r}{ }^{\max }+W p_{r}, \quad \lambda=6 / M, \quad \mu=6 /\left[\operatorname{Lny}_{j} \max +W_{y_{j}}\right]$,

Input price $l=\lambda\left[L n p r+W p_{r}\right]$, Output quantity $Z=\lambda \mu\left[L n y_{j}{ }^{\max }+W y_{j}\right]$

Subsequently the cost efficiency model (1) can be represented as: 


$$
\begin{aligned}
\operatorname{LnC}= & \sum_{j} \alpha_{j} \operatorname{Ln} Y_{j}+\sum_{r} \beta_{r} \operatorname{Ln} P_{r}+1 / 2 \sum_{j} \sum_{s} \chi_{j s} \operatorname{Ln} Y_{j} \operatorname{Ln} Y_{s}+ \\
& 1 / 2 \sum_{r} \sum_{q} \omega_{r q} \operatorname{Ln} P_{r} \operatorname{Ln} P_{q}+\sum_{j} \sum_{r} \delta_{j r} \operatorname{Ln} Y_{j} \operatorname{Ln} P_{r}+\sum_{j} \zeta_{j}\left(\operatorname{Cos} Z_{j}+\operatorname{Sin} Z_{j}\right)+ \\
& \sum_{r} \phi_{r}\left(\operatorname{Cos} l_{r}+\operatorname{Sin} l_{r}\right)+\sum_{j s}\left[\varphi_{j s} \operatorname{Cos}\left(Z_{j}+Z_{s}\right)+\pi_{j s} \operatorname{Sin}\left(Z_{j}+Z_{s}\right)\right]+ \\
& \sum_{j s}\left[\varpi_{j s} \operatorname{Cos}\left(Z_{j}-Z_{s}\right)+\eta_{j s} \operatorname{Sin}\left(Z_{j}-Z_{s}\right)\right]+\sum_{r q}\left[\gamma_{r q} \operatorname{Cos}\left(l_{r}+l_{q}\right)+\tau_{r q} \operatorname{Sin}\left(l_{r}+l_{q}\right)\right]+ \\
& \sum_{r q}\left[\psi_{r q r} \operatorname{Cos}\left(l_{r}-l_{q}\right)+\sigma_{r q r} \operatorname{Sin}\left(l_{r}-l_{q}\right)\right]+ \\
& \sum_{r q}\left[\kappa_{r q r} \operatorname{Cos}\left(l_{r}-l_{q}+Z_{j}\right)+\vartheta_{r q r} \operatorname{Sin}\left(l_{r}-l_{q}+Z_{j}\right)\right]+ \\
& \sum_{r q}\left[\theta_{r q j} \operatorname{Cos}\left(l_{r}-l_{q}-Z_{j}\right)+o_{r q j} \operatorname{Sin}\left(l_{r}-l_{q}-Z_{j}\right)\right]+v_{i}+v
\end{aligned}
$$

where $\mathrm{j}, \quad s=1,2, \quad r, \quad q=1, \quad 2, \quad 3 \quad$ and $\alpha, \beta, \chi, \omega \delta, \zeta, \phi, \varphi, \pi, \varpi, \eta, \gamma, \tau, \psi, \sigma, \kappa, \vartheta, \theta$ and $o$ are coefficients to be estimated. $v_{i}+v$ denotes non-random disturbance of the individual banks and random error respectively. Symmetry is imposed on the translog portion of the model. The trigonometric vectors within the model are chosen a priori as opposed to pre-testing. Linear homogeneity is imposed through the use of opposite signs in the input price vectors and imposing the restriction that parameters of the input price vector sum to zero (Mitchell and Onvural 1996). Monotonicity and quasi-concavity in input prices are not imposed due to the semi-non-parametric (non-multiplicative) technique underlying the flexible Fourier functional form. ${ }^{9}$ The coefficient estimates for the cost model are reported in Appendix 2. The values of the inefficiency scores can be interpreted as follows: an efficiency score of 1.11 means that the bank's costs are $11 \%$ higher than the costs of an equivalent bank that is efficient.

\footnotetext{
${ }^{9}$ Gallant (1981) stressed this does not hinder the flexible Fourier form from closely approximating the true cost function.
} 
A time series, cross-sectional regression model is employed to consider the effect of merger on the level of interest rate change. The continuously compounded rate of interest is assessed following an approach suggested by Kim and Singal (1993), Prager and Hannan (1998) and Kahn et al (2005). ${ }^{10}$ For the different banking services considered the following equation (5) is estimated for all banks:

$$
\operatorname{ratchg}_{i t}=\alpha+\sum_{m=1}^{M} \delta_{m} M_{i t}+\sum_{n=-24}^{+72} \beta_{n} A_{i t}+\sum_{n=-24}^{-1} \chi_{n} T_{i t}+\mathcal{E}_{i t}
$$

Where ratchg $_{i t}=\ln \left(\right.$ rate $_{i t} /$ rate $\left._{i(t-1)}\right)$ is the continuously compounded rate of interest rate change for the end of the month $t-1$ for the interest rate by bank $i$ for a particular type of banking service and quantity invested or borrowed, $\alpha$ is a constant value, specific to the type of banking product. These 194 monthly variables $(M)$ denote the monthly periods, where when $M$ equals $t$ a value of 1 is recorded. This is the period when the monthly dummy variable and the observed month coincide. All other periods are recorded as $M$ equals 0 . These variables are employed to reflect the effects of time on the degree of change in bank-specific interest rates, such as the effects caused by a change in official interest rates for example. Assessing whether an acquiring or target bank has merged within the sample period is indicated by the dummy variables $\beta_{n} A_{i t}$ or $\chi_{n} T_{i t}$ where $A$ indicates an acquiring bank and $T$ denotes a target bank. These dummy variables have a value of 1 if the merger has occurred in either the 24 months before the merger event for both acquiring $(A)$ and

\footnotetext{
${ }^{10}$ This examination of interest rate change does not use econometric time series techniques such as cointegration to quantify the speed of interest rate changes. These statistical techniques are not employed as product-specific retail interest rate data displays a substantial degree of clustering, around certain digits and factions (see Ashton and Hudson 2006, Kahn et al 1999). The non-random and discrete data characteristics associated with data clustering are inconsistent with co-integration methods, which depend on random and continuous data for non-biased estimation.
} 
target $(T)$ banks, and in the 72 months after the merger event for acquiring $(A)$ banks. These time periods where chosen arbitrarily yet are informed by past evidence (Focarelli and Panetta 2003) which recorded that interest rate changes from mergers can develop over substantial periods of time. In total 97 monthly variables for acquiring banks and 24 variables for target banks are estimated. $\varepsilon_{i t}$ is a non-zero error term. Following Prager and Hannan (1998) the model is estimated using an OLS estimator with Huber-White robust standard errors. This approach is adopted to overcome the potential problem of similar levels of interest rate change being reported for different banks in repeated time periods. These models are estimated for both distinct banking products and different levels of financial involvement by customers.

From this model the coefficients of particular interest are the estimates for acquiring banks $\left(\beta^{\prime} \mathrm{s}\right)$ and target banks $\left(\chi^{\prime} \mathrm{s}\right)$. These coefficients indicate the direction and statistical significance of the influence of merger events on interest rate change. For deposits a positively signed and statistically significant $\beta$ or $\chi$ would suggest merger has lead to a better rate of interest for the customer. Conversely for credit products a positively signed and statistically significant $\beta$ or $\chi$ would suggest an increase in the cost of borrowing. A zero value for $\beta$ or $\chi$, or a value which is not statistically significant, would indicate no change in interest rates for both deposit and credit products. A negatively signed and statistically significant $\beta$ or $\chi$ would indicate worse rates for investors or depositors and better rates for borrowers. The values for the $\beta$ s or $\chi^{\prime} \mathrm{s}$ are collated to provide cumulative measures of the effect of mergers on interest rates. The pre-merger effect of merger on interest rates 24 months before the merger event are recorded for both acquiring banks and the target banks as $\Sigma \beta_{(\mathrm{n}=-24 \text { to -1) }}=0$. Intermediate influences of merger recorded from 0 to 24 months after the merger 
event for acquiring banks are assessed as $\sum \beta_{(\mathrm{n}=0 \text { to 24) }}=0$. Long-term influences of merger recorded from 25 to 72 months after the merger event for acquiring banks as $\sum \beta_{(\mathrm{n}=24 \text { to 72) }}=0$. Total effects of the bank merger on interest rate change are recorded as $\sum \beta_{(-24 \text { to }+72)}=0$ values for the acquiring bank. Total effects of the bank merger on interest rate change for target banks in the 24 month prior to the merger event are recorded as $\sum_{\left.\chi_{(\mathrm{n}=24} \text { to }-1\right)}=0$.

\section{Results}

The assessment of cost efficiency and bank-specific characteristics for merging and non-merging banks is displayed in Table 3 . The pertinent findings considering the pre-merger, intermediate, long-term and total effects of merger on interest rates are displayed in Table 4 for all banks. Due to space constraints the regression coefficient values for the interest rate models are not reported and are available on request from the corresponding author.

\subsection{Cost Efficiency and Bank Characteristics}

Table 3 reports the frequency of UK bank mergers, the average levels of bank efficiency for each year, and the average levels of cost efficiency, for merging and non-merging banks. Within this table it is identified that most UK bank mergers occurred in the first half of the sample period. Further, the average level of interest paid or payable on three representative banking services and quantities are reported. These rates display a strong decline across the sample period, making meaningful 
comparisons of interest rates at different time periods problematic. Overall, the level of bank efficiency averages 1.17 indicating a 17\% efficiency difference exists between the average efficiency bank and a bank with best practice efficiency characteristics. The relative level of dispersion in the level of efficiency remains fairly constant in most years. Overall the merging banks are viewed to have higher levels of cost efficiency over the entire sample period and acquiring banks are seen to have higher cost efficiency than target banks.

Within the lower panel of Table 3 differences between bank-specific variables and efficiency for merging and non-merging banks are recorded five years before and after mergers for target and acquiring banks respectively. Acquiring banks have a statistically significant higher average level of efficiency, which improves in the years after the merger event. This finding is consistent with both previous empirical evidence (Haynes and Thompson 1999) and with past regulatory assessments (e.g. Competition Commission 2001) which have emphasised the efficiency enhancing potential of UK bank mergers. This efficiency profile is also representative of merging banks appreciating longer-term efficiency gains in the manner predicted by Focarelli and Panetta (2003). For target banks efficiency improvement is observed prior to merger, with target banks on average having lower levels of average efficiency than acquiring banks.

\subsection{Regression Model Findings}

The regression models reported in Table 4 are estimated for all banks and provide an indication as to the effect of merger events on the pricing of banking products. The model fit for the regression models using deposits and mortgage data is far more 
robust than that observed for unsecured loans; probably a result of the lower level of significant coefficient estimates obtained for this model and the smaller number of observations considered for unsecured loans. For most models the restrictions imposed are significant, and relatively high values of the coefficient of determination are recorded relative to those reported by Prager and Hannan (1998) and Kahn et al (2005).

The strongest finding from this assessment is that for most banking services, including instant access deposits, mortgage lending and unsecured lending, the effect of merger events on interest rate setting is not significantly different from zero. This finding is consistent both before mergers, in the immediate zero to two year merger period and up to and including six years after the merger.

The effect of merger on notice deposit accounts in contrast to the other banking products does appear to be statistically significant. For larger quantities ( $£ 5,000$ and $£ 50,000)$ invested in notice deposit accounts, a consistent negative change in the interest rates received by customers is recorded. This reduction in the level of interest received by these customers occurs both immediately after the merger event and up to six years after the merger event. In total the effect of this change on notice deposit interest rates can be interpreted as a major decline in the level of interest received by customers relative to non-merging banks. Clearly, this provides strong evidence that merging banks compete far less aggressively in the market for notice deposits. Conversely, before mergers, target banks appear to be pricing their notice deposit account for smaller quantities ( $£ 500$ and $£ 5000$ ) relatively aggressively and providing significantly higher rates of interest in the two years before the merger occurs. 
Overall, we suggest that the process of merger appears to be associated with a strategic change away from the competitive provision of notice deposits. 
Table 3: $\quad$ The Distribution of Efficiency and Average Interest Rates

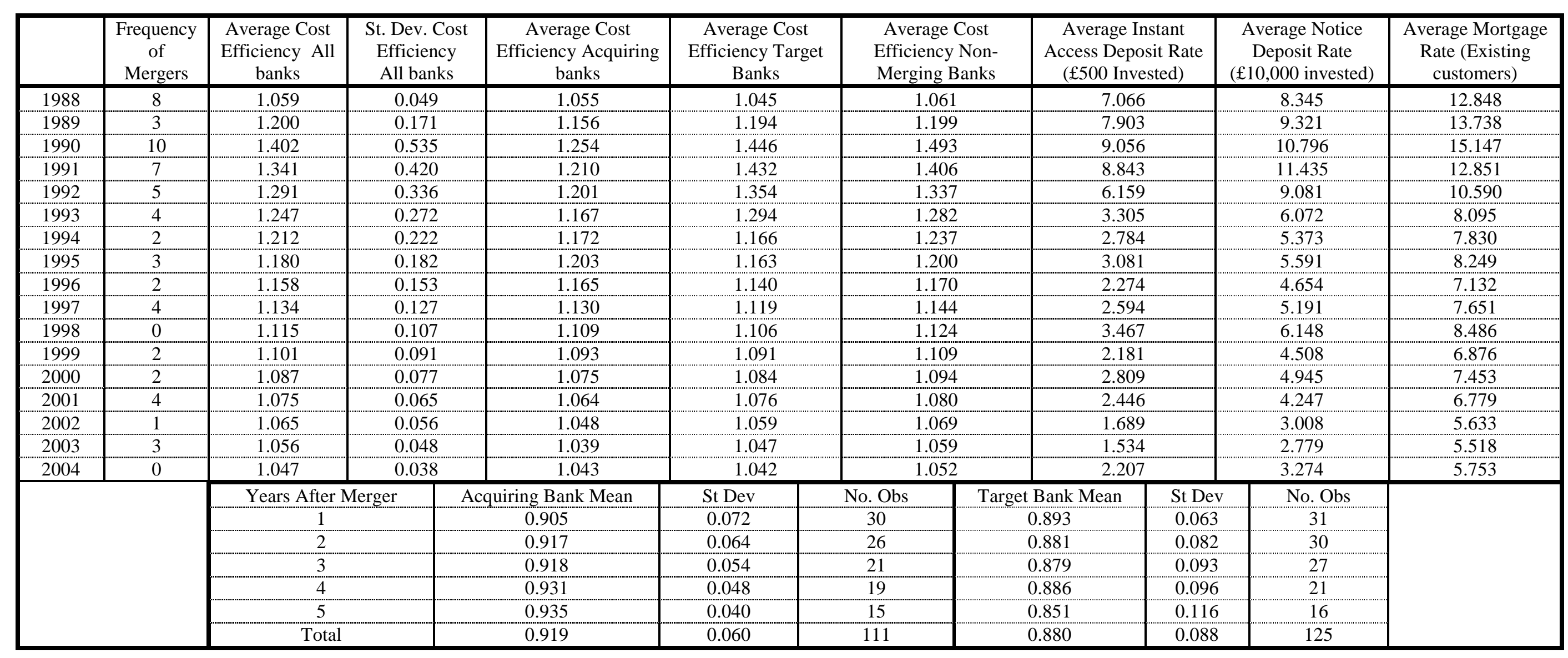


Table 4: Impact of Mergers on Bank Deposit Interest Rates: All Banks

\begin{tabular}{|c|c|c|c|c|c|c|c|c|c|c|c|}
\hline \multicolumn{8}{|c|}{ Instant access } & \multicolumn{4}{|c|}{ Notice accounts } \\
\hline & & \multicolumn{2}{|c|}{$£ 500$} & \multicolumn{2}{|c|}{$£ 5,000$} & \multicolumn{2}{|c|}{$£ 50,000$} & \multicolumn{2}{|c|}{$£ 500$} & \multicolumn{2}{|c|}{$£ 5,000$} \\
\hline \multirow{2}{*}{$\begin{array}{l}\text { Target } \\
\text { Bank }\end{array}$} & & Coef. & $\mathrm{t}$ & $\mathrm{P}>\mathrm{t}$ & Coef. & $\mathrm{t}$ & $\mathrm{P}>\mathrm{t}$ & Coef. & $\mathrm{t}$ & Coef. & $\mathrm{t}$ \\
\hline & Before Merger Target & 0.123 & 1.150 & 0.251 & -0.008 & -0.130 & 0.893 & $0.614^{*}$ & 1.690 & $1.487^{*}$ & 3.560 \\
\hline \multirow{7}{*}{ 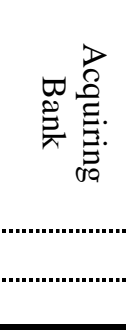 } & Before Merger & 0.006 & 0.100 & 0.923 & -0.005 & -0.130 & 0.897 & -0.266 & -1.120 & -0.465 & -1.160 \\
\hline & Intermediate Change & -0.084 & -0.910 & 0.362 & 0.045 & 0.980 & 0.325 & 0.113 & 0.550 & -0.321 & -0.680 \\
\hline & Long-run Change & 0.125 & 0.600 & 0.546 & -0.002 & -0.020 & 0.983 & -0.253 & -0.810 & $-1.927 *$ & -2.780 \\
\hline & Total Change & 0.073 & 0.350 & 0.726 & 0.033 & 0.370 & 0.710 & -0.581 & -1.580 & $-2.895^{*}$ & -3.620 \\
\hline & Observations & \multicolumn{2}{|c|}{13015} & \multicolumn{2}{|c|}{136439} & \multicolumn{2}{|c|}{13660} & \multicolumn{2}{|c|}{11667} & \multicolumn{2}{|c|}{10668} \\
\hline & F test & \multicolumn{2}{|c|}{$\mathrm{F}(312,12702)=18.54 * *$} & \multicolumn{2}{|c|}{$\mathrm{F}(312,13336)=30.32 * *$} & \multicolumn{2}{|c|}{$\mathrm{F}(312,13347)=21.64 * *$} & \multicolumn{2}{|c|}{$\mathrm{F}(312,11354)=2.71 * *$} & \multicolumn{2}{|c|}{$\mathrm{F}(312,10355)=8.79 * *$} \\
\hline & $\mathrm{R}^{2}$ & \multicolumn{2}{|c|}{0.1720} & \multicolumn{2}{|c|}{0.2601} & \multicolumn{2}{|c|}{0.2760} & \multicolumn{2}{|c|}{0.1509} & \multicolumn{2}{|c|}{0.2242} \\
\hline \multicolumn{4}{|c|}{ Notice accounts } & \multicolumn{4}{|c|}{ Unsecured lending } & & & \multicolumn{2}{|c|}{ Mortgage lending } \\
\hline \multirow{3}{*}{$\begin{array}{l}\text { Target } \\
\text { Bank }\end{array}$} & & \multicolumn{2}{|c|}{$£ 50,000$} & \multicolumn{2}{|c|}{$£ 500$} & \multicolumn{2}{|c|}{$£ 5,000$} & \multicolumn{2}{|c|}{$£ 10,000$} & & \\
\hline & & Coef. & $t$ & Coef. & t & Coef. & te.... & 0.043 & 0.520 & Coef. & $\mathrm{t}$ \\
\hline & Before Merger Target & 0.288 & 0.570 & -0.027 & -0.330 & 0.041 & 0.550 & 0.053 & 0.990 & 0.002 & 0.180 \\
\hline & Before Merger & -0.052 & -0.130 & 0.018 & 0.340 & 0.084 & 1.410 & 0.097 & 1.650 & -0.006 & -0.810 \\
\hline$-\stackrel{8}{8}$ & Intermediate Change & -0.557 & -1.130 & 0.045 & 0.670 & 0.059 & 1.150 & -0.006 & -0.060 & 0.000 & 0.010 \\
\hline$\stackrel{\Xi}{E}$. & Long-run change & $-3.401 *$ & -4.610 & 0.002 & 0.030 & -0.024 & -0.190 & 0.133 & 1.070 & 0.000 & -0.040 \\
\hline 宫 & Total change & $-4.164 *$ & -4.900 & 0.075 & 0.680 & 0.117 & 0.840 & 0.043 & 0.520 & -0.005 & -0.480 \\
\hline & Obs. & & & & & & & & & & \\
\hline & $\mathrm{F}$ test & $\mathrm{F}(312,10$ & $=15.29 * *$ & & & $\mathrm{~F}(278$ & $5)=1.1$ & & & $\mathrm{~F}(313,13$ & $=42.41$ \\
\hline & $\mathrm{R}^{2}$ & & & & & & & & & & \\
\hline
\end{tabular}

* indicates statistical significance at $10 \%$, ** indicates significance at $1 \%$. 


\section{Conclusions and Policy Recommendations}

This study quantifies the influence of mergers on the level of interest payable on retail deposits and loans, and cost efficiency for UK banks. Initially, UK bank mergers are seen to be cost efficiency enhancing. This finding is consistent with past work of Haynes and Thompson (1991) and indicates that the time over which efficiency gains are realised is substantial, with statistically significant efficiency gains appreciated even five years after the merger event.

The effect of bank mergers on retail interest rates is mostly statistically insignificant. This finding is in many regards at odds with findings reported for the US (Prager and Hannan 1998) or Italian (Focarelli and Panetta 2003) banking markets, where mergers are seen to have a stronger and negative influence on interest rates. This difference may exist for many reasons, including differences in the market structure of the banking markets considered. This study, distinct from past work, considers a large, and in many regards national, banking market (see Ashton 2001b), as opposed to relatively small regional markets. It is also possible that the influence of bank mergers over market power may be far more limited in larger national markets.

The findings for efficiency and interest rates are broadly consistent with the theoretical framework proposed by Farrell and Shapiro (1990). These authors indicated that large changes in efficiency are required to overcome price rising effects of mergers. The situation where interest rates are in many cases unmoved by moderate efficiency improvements as observed in this study is consistent with this perspective. 
To conclude, this study assesses the combined efficiency and price effects which follow banks mergers. It is reported that the degree of pass through from efficiency gains to prices is both limited and varies by product type. These findings contrast with contemporary approaches to assessing the impact of mergers through a proxy such as market share (see Werden 2002). It is proposed that the price and efficiency effects which emerge from mergers may not be clearly understood through assessment of market share change alone. Further, future work assessing the impact of mergers may choose to investigate possible differential pricing and efficiency effects which develop from the merger process. 


\section{References}

Aigner, D., Lovell, K. and Schmidt, P. (1997). "Formulation and Estimation of Stochastic Frontier Production Function Models", Journal of Econometrics, vol.6, pp. 21-37.

Altunbas, Y., Gardener, E. P. M., Molyneux, P. and Moore, B. (2001). "Efficiency in European banking”, European Economic Review, vol.45, pp. 1931-1955.

Altunbas, Y., Molyneux, P. and Thornton, J. (1997). "Big-Bank Mergers in Europe. An Analysis of the Cost Implications”, Economica, vol.64, pp.317-329.

Amel, D., Barnes, C., Panetta, F. and Salleo. C., "Consolidation and efficiency in the financial sector: A review of the international literature", Journal of Banking and Finance, vol.28, no.10, pp. 2493-2519.

Ashton, J. K. (2001a). "Efficiency Characteristics of the British Retail Banking Sector", The Service Industries Journal, vol.21, no.2, pp. 159-174.

Ashton, J. K. (2001b). "Market Definition in the UK Deposit Savings Account Market”, Regional Studies, vol.35, no.6, pp.577-590.

Ashton, J. K. and Hudson, R. (2006). "Interest Rate Clustering in UK Financial Services Markets", CCP Working Paper, No. 06-14, ESRC Centre for Competition Policy, University of East Anglia, Norwich.

Azzam, A. (1997). "Measuring Market Power and Cost Efficiency Effects of Industrial Concentration", The Journal of Industrial Economics, vol.45, no.4, pp.377386.

Azzam, A. and Rosenbaum, D. (2001). "Differential efficiency, market structure and price", Applied Economics, vol.33, pp.1351-1357.

Banker, R. D., Charnes, A. and Cooper, W. W. (1984). "Some Models for Estimating Technical and Scale Inefficiencies in Data Envelopment Analysis", Management Science, vol.30, no. 9, pp. 1078-02. 
Barnes, P. (1985). "UK Building Societies - A Study of the Gains from Merger", Journal of Business, Finance and Accounting, vol.12, no.1, pp. 75-91.

Berger, A. N., Demsetz, R. S. and Strahan, P. E. (1999). "The consolidation of the financial services industry: Causes, consequences and implications for the future", Journal of Banking and Finance, vol.23, pp.135-194.

Berger, A. N. and Humphrey, D. B. (1997). "Efficiency of financial institutions: international survey and directions for future research" European Journal of Operational Research, vol. 98, pp.175-212.

Battese, G. E and Coelli, T. J. (1992), "Frontier Production Functions, Technical Efficiency and Panel Data: with Applications to Paddy Farmers in India”, Journal of Productivity Analysis, vol.3, pp. 153-169.

Bulow, J. I. and Pfleiderer, P. (1985). "A Note on the Effect of Cost Changes on Prices”, Journal of Political Economy, vol.91, no.1, pp. 182-185.

British Bankers Association, (various editions 1988-2004). Annual Abstract of Banking Statistics, London.

Casu, B. and Girardone, C. (2006). "Bank Competition, Concentration and Efficiency in the Single European Market”, The Manchester School, vol.74, no.4, pp.441-468.

Campa, J. M. and Hernado, I. (forthcoming) "M \& As performance in the European financial industry", Journal of Banking and Finance.

Carrow, K. A., Kane, E. J. and Narayanan, R. P. (2006). "How Have Borrowers Fared in Banking Megamergers", Journal of Money, Banking and Credit, vo.38, no.3, pp.821-836.

Chalfant, J. A. and Gallant, A. R. (1985). "Estimating substitution elasticities with the Fourier cost function”, Journal of Econometrics, vol.28, pp.205-222. 
Charnes, A., Cooper, W. W. and Rhodes, E. (1978). "Measuring the Efficiency of Decision Making Units”, European Journal of Operational Research, vol.2, no.6, pp. 429-444.

Competition Commission. (2001). Lloyds TSB Group plc and Abbey National plc: A Report on the Proposed Merger, CM 5208, London.

Costanzo, L. and Ashton, J. K. (2006). "Product Innovation and Consumer Choice in the UK Financial Services Industry", Journal of Financial Regulation and Compliance, vol.14, no.3, pp. 285-303.

Cruickshank, D. (2000) “Competition in UK banking. A Report to the Chancellor of the Exchequer", The Stationary Office, London.

Davis, D. and Wilson B. J. (2000). "Firm-specific cost savings and market power", Economic Theory, vol.16, pp.545-565.

Djelic. M. L. (2002). Does Europe mean Americanization? The Case of Competition, Competition and Change, vol.6, no. 3, pp.223-250.

Drake, L, and Llewellyn, D. T. (2001). "The economics of mutuality: a perspective on UK building Societies", in Birchall, J. (2001), The New Mutualism in Public Policy, Routledge, London.

Farrell, J. and Shapiro, C. (1990). "Horizontal Mergers: An Equilibrium Analysis", American Economic Review, vol.80, no.1, pp.107-126.

Focarelli, D., Panetta, F. and Salleo, C. (2002). "Why do banks merge?”, Journal of Money Credit and Banking, vol.34, no.4, pp.1047-1066.

Focarelli, D. and Panetta, F. (2003). "Are Mergers Beneficial to Consumers? Evidence from the Market for Bank Deposits", The American Economic Review, vol.93, no.4, pp.1152-1172. 
Froeb, L., Tschantz, S. and Werden, G. J. (2005). "Pass-through rates and the price effects of mergers”, International Journal of Industrial Organization, vol.23, pp.703715.

Gallant, A. R. (1981). "On the bias in flexible functional forms and an essentially unbiased form", Journal of Econometrics, vol.15, pp. 211-245.

Gallant, A. R. (1982). "Unbiased Determination of Production Technologies", Journal of Econometrics, vol.20, pp. 285-323.

Haynes, M. and Thompson, S. (1999). "The Productivity effects of bank mergers: Evidence from the UK building societies", Journal of Banking and Finance, vol.23, pp. $825-846$.

Heffernan, S. A. (2005) "The effect of UK building society conversion on pricing behaviour", Journal of Banking and Finance, vol.29, pp.779-797.

Heffernan, S. A. (2006). "UK Bank Services for Small Business: How competitive is the market", Journal of Banking and Finance, vol. 30, pp.3087-3110.

Ivaldi, M., Ladoux, N., Ossard, H. and Simioni, M. (1996). “Comparing Fourier and Translog specifications of multiproduct technology: Evidence from an incomplete panel of French farmers", Journal of Applied Econometrics, vol.11, pp. 649-667.

Kahn, C., Pennacchi, G. and Sopranzetti, B. (1999). "Bank Deposit Rate Clustering: Theory and Empirical Evidence", The Journal of Finance, vol. 54, no.6, pp.21852214.

Kahn, C., G. Pennacchi, and B. Sopranzetti, (2005). "Bank Consolidation and the Dynamics of Consumer Loan Interest Rates", Journal of Business, vol.78, no.1, pp. 99-133.

Karceski, J., Ongena, S. amd D. C. Smith, (2005). “The Impact of Bank Consolidation on Commercial Borrower Welfare”, Journal of Finance, vol. 60, no.4, pp.2043-2082. 
Kim, E. H. and Singal, V. (1993). "Mergers and Market Power: Evidence from the Airline Industry", The American Economic Review, vol. 83, no.3, pp.549-569.

Lopez, R. A., Azzam, A. M., and Lirón-España, C. (2002). "Market Power and/or Efficiency: A Structural Approach", Review of Industrial Organization, vol.20, pp.115-126.

Mitchell, K. and Onvural, N. M. (1996). "Economies of scale and scope at large commercial banks: Evidence from the Fourier flexible functional form", Journal of Money, Credit and Banking, vol.28, no.2, pp.178-199.

Moneyfacts Magazine, various editions (1988-2004), Moneyfacts Group, Norwich, UK. Nicols, A. (1967). "Stock Versus Mutual Savings and Loan Associations: Some Evidence of Differences in Behaviour", The American Economic Review, vol.57, pp.337-346.

Pesendofer, M. (2003). "Horizontal mergers in the paper industry", RAND Journal of Economics, vol.34, no.3, pp.495-515.

Prager, R. A. and Hannan, T. H. (1998). "Do Significant Horizontal Mergers Generate Significant Price Effects? Evidence from the Banking Industry", The Journal of Industrial Economics, vol. 46, no.4, pp.433-452.

Röller, L. H., Stennek, J. and Verboven, F. (2000). Efficiency Gains from Mergers", Discussion Paper FS IV, no. 00-09, Wissenschaftszentrum Berlin für Sozialforschung, Berlin.

Rossi, P .E. (1985). "Comparisons of Alternative functional Forms in Production", Journal of Econometrics, vol.30, pp.345-61

Sapanieza, P. (2002). "The Effects of Banking Mergers on Loan Contracts", The Journal of Finance, vol. 57, no.1, pp.329-367. 
Sealey, C. W. and Lindley, J. T. (1977). "Inputs, outputs, and a theory of production and cost at depository financial institutions", The Journal of Finance, vol.32, no.4, pp.1252-1253.

Spector, D. (2003). "Horizontal mergers, entry and efficiency defences", International Journal of Industrial Organization, vol.21, pp.1591-1600.

Stuyck, J. (2005). "EC Competition Law After Modernisation: More Than Ever in the Interest of Consumers", Journal of Consumer Policy, vol.28, pp 1-30.

Ten Kate, A. and Niels, G. (2005). "To What Extent are Cost Savings Passed on to Consumers? An Oligopoly Approach", European Journal of Law and Economics, vol.20, pp.232-337.

Werden, G. J. (2002). “Assigning Market Shares”, Antitrust Law Journal, vol.70, pp. 67-104.

Williamson, O. E. (1968). "Economies as an Antitrust Defense: The Welfare Tradeoffs", The American Economic Review, vol.58, no.1, pp.18-36. 
Appendix 1: UK bank mergers 1988- 2004

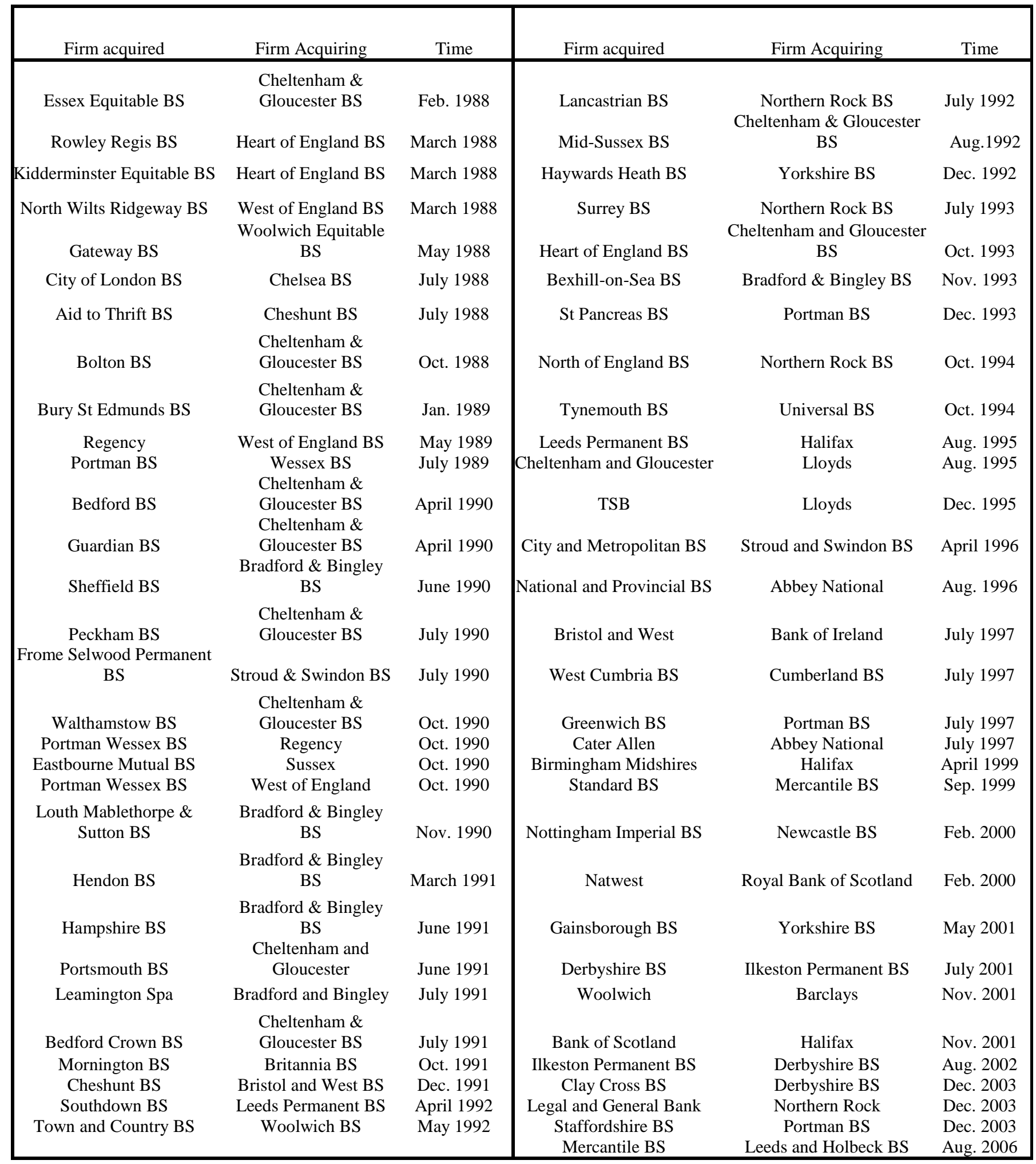




\section{Appendix 2: Cost Efficiency model coefficient estimates}

\begin{tabular}{|c|c|c|c|c|c|c|c|c|}
\hline $\operatorname{lnc}$ & Coeff. & Std. Err. & $\operatorname{lnc}$ & Coeff. & Std. Err. & $\operatorname{lnc}$ & Coeff. & Std. Err. \\
\hline Constant & -0.218 & $(0.892)$ & $\chi_{11}$ & $-0.238 * *$ & $(0.054)$ & $\theta_{122}$ & 0.007 & $(0.096)$ \\
\hline$\beta_{1}$ & 0.212 & $(0.188)$ & $\chi_{22}$ & $-0.191 * *$ & $(0.063)$ & $\theta_{131}$ & 0.148 & $(0.097)$ \\
\hline$\beta_{2}$ & -0.502 & $(0.307)$ & $\omega_{11}$ & $0.156 * *$ & $(0.041)$ & $\theta_{132}$ & -0.143 & $(0.101)$ \\
\hline$\beta_{3}$ & $-0.692 * *$ & $(0.148)$ & $\omega_{22}$ & -0.122 & $(0.080)$ & $\theta_{231}$ & $-0.454 * *$ & $(0.103)$ \\
\hline$\alpha_{1}$ & $2.651 * *$ & $(0.282)$ & $\omega_{33}$ & $-0.033 * *$ & $(0.012)$ & $\theta_{232}$ & $0.368 * *$ & $(0.107)$ \\
\hline$\alpha_{2}$ & $-1.919 * *$ & $(0.280)$ & $\chi_{12}$ & $0.213 * *$ & $(0.057)$ & $\vartheta_{121}$ & 0.145 & $(0.089)$ \\
\hline$\gamma_{12}$ & 0.014 & $(0.030)$ & $\omega_{12}$ & -0.091 & $(0.061)$ & $\vartheta_{122}$ & -0.104 & $(0.092)$ \\
\hline$\gamma_{13}$ & -0.017 & $(0.026)$ & $\omega_{13}$ & $-0.044 *$ & $(0.018)$ & $\vartheta_{131}$ & -0.021 & $(0.089)$ \\
\hline$\gamma_{23}$ & -0.016 & $(0.026)$ & $\omega_{23}$ & $0.192 * *$ & $(0.046)$ & $\vartheta_{132}$ & -0.034 & $(0.094)$ \\
\hline$\psi_{12}$ & $0.125^{*}$ & $(0.053)$ & $\sigma_{11}$ & 0.061 & $(0.042)$ & $\vartheta_{231}$ & $0.177^{*}$ & $(0.097)$ \\
\hline$\psi_{13}$ & -0.004 & $(0.039)$ & $\sigma_{12}$ & -0.040 & $(0.097)$ & $\vartheta_{232}$ & -0.066 & $(0.102)$ \\
\hline$\psi_{23}$ & -0.030 & $(0.049)$ & $\sigma_{13}$ & $0.200 * *$ & $(0.042)$ & $\mathrm{O}_{121}$ & 0.056 & $(0.074)$ \\
\hline$\tau_{12}$ & $-0.093^{*}$ & $(0.046)$ & $\sigma_{31}$ & -0.058 & $(0.040)$ & $\mathbf{O}_{122}$ & 0.013 & $(0.077)$ \\
\hline$\tau_{13}$ & 0.000 & $(0.000)$ & $\sigma_{32}$ & 0.140 & $(0.100)$ & $\mathrm{O}_{131}$ & $-0.212^{*}$ & $(0.093)$ \\
\hline$\tau_{23}$ & -0.008 & $(0.053)$ & $\sigma_{33}$ & $-0.205^{* *}$ & $(0.046)$ & $\mathrm{O}_{132}$ & $0.160 *$ & $(0.096)$ \\
\hline$\rho_{12}$ & $0.105^{*}$ & $(0.043)$ & $\kappa_{121}$ & $0.334 * *$ & $(0.082)$ & $\mathrm{O}_{231}$ & 0.074 & $(0.099)$ \\
\hline$\rho_{13}$ & $-0.106^{* *}$ & $(0.031)$ & $\kappa_{122}$ & $-0.251 * *$ & $(0.082)$ & $\mathrm{O}_{232}$ & 0.027 & $(0.103)$ \\
\hline$\rho_{23}$ & $0.175 * *$ & $(0.035)$ & $\kappa_{131}$ & $-0.185^{*}$ & $(0.096)$ & $\zeta_{11}$ & $-0.304 * *$ & $(0.091)$ \\
\hline$\varphi_{12}$ & -0.020 & $(0.018)$ & $\kappa_{133}$ & 0.104 & $(0.097)$ & $\zeta_{22}$ & $0.211 *$ & $(0.096)$ \\
\hline $\bar{\omega}_{12}$ & $-1.202 * *$ & $(0.266)$ & $\kappa_{231}$ & $0.271 * *$ & $(0.095)$ & $\phi_{11}$ & $0.129 *$ & $(0.058)$ \\
\hline$\pi_{12}$ & -0.017 & $(0.018)$ & $\kappa_{232}$ & $-0.239^{*}$ & $(0.095)$ & $\phi_{22}$ & -0.077 & $(0.060)$ \\
\hline$\eta_{12}$ & $-1.353^{*} *$ & $(0.118)$ & $\theta_{121}$ & -0.034 & $(0.090)$ & $\phi_{33}$ & 0.017 & $(0.057)$ \\
\hline \multicolumn{9}{|c|}{$\begin{array}{l}\text { Number of Observations }=1394 \\
\text { Wald Test }=46490.77\end{array}$} \\
\hline
\end{tabular}

* indicates statistical significance at $10 \%$, ** indicates significance at $1 \%$. 